\title{
Praca z traumą relacyjną w terapii par
}

Funkcjonowanie człowieka w jego relacjach małżeńskich, rodzinnych i ogólnospołecznych bardzo często jest naznaczone przeżyciem różnego typu trudnych doświadczeń, określanych mianem traumy. Chodzi tu o te wydarzenia, które mają miejsce począwszy od zarania istnienia aż po krańce ludzkiego życia, a wywołane są różnymi stresorami. Zasadniczo można wyróżnić traumy wynikające z wydarzeń losowych, anomalii przyrody, różnych wypadków oraz traumy powstałe na skutek destrukcyjnych i dysfunkcyjnych zachowań innych osób. W niniejszym opracowaniu skupimy się na tych traumach, które zostały nabyte w ramach relacji interpersonalnych (traumy relacyjne), i to z osobami znaczącymi, gdyż ich wpływ ma często rozstrzygający charakter dla dalszego rozwój konkretnego człowieka oraz jego umiejętności budowania poprawnych relacji interpersonalnych w małżeństwie i rodzinie.

Zazwyczaj intensywne przeżycia towarzyszące trudnym wydarzeniom, doświadczane w relacjach, tak głęboko wpisują się w świadomość danej osoby, iż rzutują na rozumienie świata, styl dalszego funkcjonowania, sposób nawiązywania i utrzymywania relacji międzyosobowych, a nawet mogą odcisnąć swe piętno w strukturze kształtującej się osobowości. Przynoszą one zatem istotne zmiany w sposobie postrzegania siebie, innych ludzi, 
świata i zazwyczaj kładą się swoistym „cieniem” na ich życiu, który w znacznym stopniu może obniżać jego jakość.

Początkowo obciążenia wynikające $\mathrm{z}$ traumatycznych doświadczeń relacyjnych zaczynają być odbierane w funkcjonowaniu indywidualnym, lecz swe apogeum osiągają w trakcie funkcjonowania wobec osób bliskich, szczególnie w nowych związkach. Bowiem dopiero poprzez przeżywany trud w nawiązywaniu, rozwijaniu i utrzymywaniu bliskich relacji partnerskich wiele osób uświadamia sobie rolę traum w ich życiu. Pod wpływem przymusu powtarzania i rozgrywania tak żywo obecnych wewnątrz zranień i następstw traumy poszczególne jednostki przenoszą ją na relacje w swych związkach małżeńskich. Na kolejnych etapach funkcjonowania związku od poznania się aż po wejście w role małżeńskie i rodzicielskie osoby straumatyzowane i ich partnerzy zauważają potężne trudności w budowaniu szczęśliwych relacji.

Powstaje zasadnicze pytanie: czy można takim parom skutecznie pomóc, gdy pod wpływem dawnych trudnych doświadczeń, które aktualizują się w ich związku, następują kolejne traumy wzajemnych zranień? Jakie zastosować działania leczące? Na ile terapia par stanie się skutecznym narzędziem przynoszącym im pomoc i pozwoli przepracować nabyte i aktualnie zadawane rany oraz cierpienia? By podjąć próbę odpowiedzi na powyższe pytania, zostaną poruszone następujące zagadnienia - wyjaśnienie pojęcia tramy, traumy relacyjnej i traumy relacyjnej pary, następnie przedstawione zostaną wybrane terapie par, których założenia teoretyczne pozwalają podjąć praktyczne oddziaływania wobec traum przeżywanych przez pary w ich życiu.

\section{Pojęcie traumy, traumy relacyjnej i traumy relacyjnej pary}

Traumę definiuje się często jako doświadczenie, które konfrontuje człowieka ze strachem czy bezradnością. Kluczowym elementem są emocje, odczuwanie sytuacji przez jednostkę - to właśnie one decydują o tym, czy dane wydarzenie będzie traumatyczne, czy też nie ${ }^{1}$. W szerokim ujęciu traumą

1 A. Popiel, E. Pragłowska, Psychopatologia reakcji na traumatyczne wydarzenia, w: Konsekwencje psychiczne traumy - uwarunkowania i terapia, red. J. Strelau, B. Zawadzki, M. Kaczmarek, Warszawa 2009, s. 38. 
można nazywać wszelkie urazy psychiczne występujące na różnych etapach życia człowieka (kryzysy, konflikty, zagrażające życiu przewlekłe choroby somatyczne i psychiczne), które łączą się z ryzykiem wystąpienia emocjonalnych, poznawczych i społecznych zaburzeń. Takie rozumienie traumy zbliżone jest do pojęcia sytuacji stresowej. W rozumieniu wąskim trauma jest traktowana jako rodzaj ciężkiego stresora, który powoduje narażenie na utratę życia lub poważne zranienie ciała, ma najczęściej charakter nagły, niekontrolowany, może dotyczyć wielu osób równocześnie. Odnosi się to także do sytuacji, w której osoba jest świadkiem takiego wydarzenia ${ }^{2}$.

Traumę zatem stanowi uraz psychiczny spowodowany gwałtownym i przykrym przeżyciem, zwykle związanym z zagrożeniem życia lub zdrowia, np. gwałt, wypadek samochodowy lub doświadczenie bojowe. Sytuacje wywołujące traumę mogą być wywołane przez czynniki niezależne od człowieka (klęski żywiołowe) lub też od człowieka zależne. Przykładami tego typu katastrof mogą być wszelkiego rodzaju wypadki komunikacyjne, ale także pożary i eksplozje gazu, wyładowania z sieci elektrycznych i wszystkie wypadki porażenia prądem, katastrofy budowlane i katastrofy ekologiczne. Wśród klęsk żywiołowych, których doświadczenie może działać traumatyzująco, można wymienić trzęsienia ziemi, powodzie i nawałnice oraz pożary lasów i erupcje wulkanów. Wśród źródeł traumy powstałych z winy człowieka na wyróżnienie zasługują akty przemocy domowej (maltretowanie fizyczne i psychiczne), napady z użyciem noża, uprowadzenia, rozboje, akty terroru, strzelaniny, zamachy bombowe, gwałty, wykorzystywanie seksualne, akty bestialstwa człowieka względem człowieka (niehumanitarne więzienie, torturowanie ludzi) albo wojny, które nie zamykają tej i tak już długiej listy. Wiele innych wydarzeń może odcisnąć trwały ślad, nawet jeżeli nie wiąże się z nimi żaden akt terroru ani przemoc. Zdarzenia takie jak utrata pracy, poronienie, rozwód lub nagła śmierć kogoś bliskie także mogą zostać odebrane jako traumatyczne ${ }^{3}$.

Nagłe zdarzenie traumatyczne wywiera ogromny wpływ na poglądy ludzi o samych sobie i otaczającym ich świecie. Wywołuje dezorientację i strach, które spowodowane są nie tylko sytuacją, ale także tym, jak oso-

2 S. Steuden, K. Janowski, Trauma - kontrowersje wokół pojęcia, diagnoza, następstwa, implikacje praktyczne, „Roczniki Psychologiczne” (2016) nr 3, s. 551.

3 A. Jankowska, M. Lotkowski, Przeżywanie stresu traumatycznego w rodzinie - przyczyny, przebieg, następstwa oraz proces zdrowienia, „Kwartalnik Naukowy - Fides et Ratio” (2012) nr 1, s. 79. 
by się zachowują. Ofiarom często wydaje się, że oszalały. Borykają się z poczuciem braku kontroli nad tym, co się dzieje. Ogromną ulgę przynosi im uświadomienie, że ich zachowanie było normalne i zrozumiałe w obliczu przeżytej traumy. Ważna jest dla nich informacja, że da się rozwiązać sytuację, w jakiej się znaleźli, i pomóc im odzyskać pełne zdrowie. Terapia łącząca rozmowę i zmiany zachowania pomaga osobom po przebytej traumie odzyskać poczucie kontroli nad ich życiem. Należy jednak pamiętać, że proces ten jest indywidualny dla każdego człowieka ${ }^{4}$.

Wydarzenia traumatyczne mogą wywoływać różne reakcje człowieka. Można wyróżnić następujące rodzaje urazów ze względu na objawy postraumatyczne:

- typ I traumy: pojedyncze wydarzenia;

- typ II traumy: wielokrotne doświadczenia traumatyczne:

typ II A: możliwe jest oddzielenie od siebie poszczególnych traumatycznych sytuacji, a ofiara ma zasoby pozwalające poradzić sobie z nimi;

typ II B: niemożliwe jest oddzielenie od siebie poszczególnych traumatycznych sytuacji; ofiara ma zasoby pozwalające poradzić sobie z tymi wydarzeniami (Typ II B R) lub ofiara nie ma odpowiedniej strategii radzenia sobie z tymi doświadczeniami (Typ II B nR);

- typ III: ofiara wielokrotnie doświadczała aktów przemocy, które rozpoczęły się już w dzieciństwie i trwały jakiś czas ${ }^{5}$.

Konsekwencją traumy typu I są zazwyczaj symptomy PTSD (Posttraumatic Stress Disorder). W zakres tego zespołu wchodzą m.in. objawy intruzji (nawracania), pobudzenia i unikania ${ }^{6}$. Natomiast konsekwencje psychologiczne traum typu II i III mogą pasować do wielu kategorii diagnostycznych, ponieważ ludzie mogą w bardzo różny sposób reagować na sytuacje traumatyczne?

\footnotetext{
C. Herbert, Zrozumieć traumę - poradnik dla osób, które doznały urazu i dla ich rodzin, Gdańsk 2004, s. 20.

5 A. Popiel, E. Pragłowska, Psychopatologia reakcji na traumatyczne wydarzenia, dz. cyt., s. 39.

$6 \quad$ N. Ogińska-Bulik, Negatywne i pozytywne następstwa doświadczonej traumy - rola ruminacji, „Psychiatria, Psychologia Kliniczna” (2016) nr 3, s. 183.

$7 \quad$ A. Jankowska, M. Lotkowski, Przeżywanie stresu traumatycznego $w$ rodzinie..., dz. cyt., s. 76.
} 
W podręczniku ICD-10 z roku 1997 Światowa Organizacja Zdrowia (WHO) wymienia następujące zespoły zaburzeń psychicznych związanych przyczynowo $\mathrm{z}$ narażeniem na zdarzenia traumatyczne:

(1) Ostra reakcja na stres - definiowana jest jako przemijające zaburzenie o znacznym nasileniu, które rozwija się jako reakcja na wyjątkowy stres fizyczny lub psychiczny u osoby, która nie przejawiała wcześniej żadnego zaburzenia psychicznego. Następuje w ciągu kilku minut od wydarzenia traumatycznego, słabnie i ustępuje w ciągu kilku godzin (24-48 godzin).

(2) Zaburzenie stresowe pourazowe - pojawia się jako opóźniona i/lub przedłużona reakcja na wyjątkowo stresujące wydarzenie lub sytuację (oddziałującą krótko- lub długotrwale) o cechach wyjątkowo zagrażających lub katastroficznych, które mogłoby spowodować odczuwanie cierpienia u niemal każdego (np. gwałt, brutalna śmierć, działania wojenne, poważne katastrofy). W zaburzeniu tym występują objawy związane z ponownym przeżywaniem wydarzenia urazowego - uporczywe przypominanie sobie lub „odżywanie” stresora w postaci zakłócających „przebłysków”, żywych wspomnień lub powracających snów, albo w postaci gorszego samopoczucia w sytuacji zetknięcia się z okolicznościami przypominającymi stresor osoba unika okoliczności przypominających stresor. Charakterystycznymi objawami są także: częściowa lub całkowita niezdolność do odtworzenia pewnych ważnych okoliczności zetknięcia się ze stresorem oraz uporczywie utrzymujące się objawy zwiększonej psychologicznej wrażliwości i stanu wzbudzenia (trudności z zasypianiem i podtrzymaniem snu; drażliwość lub wybuchy gniewu; trudność koncentracji; nadmierna czujność; wzmożona reakcja przestrachu). Objawy muszą wystąpić w ciągu 6 miesięcy od stresującego wydarzenia albo od zakończenia okresu oddziaływania stresora.

(3) Zaburzenia adaptacyjne - są to stany zaburzeń emocjonalnych, które powstają w okresie adaptacji do dużych zmian życiowych lub do stresującego wydarzenia życiowego i zazwyczaj utrudniają społeczne przystosowanie i efektywne działanie. W odniesieniu do tej kategorii diagnostycznej stresor nie musi mieć charakteru ekstremalnego (trauma w rozumieniu szerokim).

(4) Trwałe zmiany osobowości po katastrofach (po przeżyciu sytuacji ekstremalnej) - rozpoznania takiego można dokonać jedynie wtedy, gdy dochodzi do wyraźnej i trwałej zmiany w dotychczasowym sposobie postrzegania, odnoszenia się do innych czy myślenia o sobie i otoczeniu. Zmiany osobowości powinny być znaczne i związane z niedostosowanymi 
i sztywnymi zachowaniami, które nie występowały przed patogennym przeżyciem ${ }^{8}$.

Wśród traum istotne miejsce zajmuje trauma relacyjna. Do jej istoty należy długotrwały proces zaniedbywania emocjonalnego we wczesnym dzieciństwie. Możemy ją zatem zdefiniować jako uraz psychiczny spowodowany przez powtarzające się wydarzenia, występujące zwykle w kontekście bliskiej relacji z osobami znaczącymi. Występowanie reakcji stresowych oraz symptomów zespołu stresu pourazowego wiązać się będzie w tym konteście z długotrwałym podleganiem niekorzystnemu wpływowi, niszczącemu równowagę psychiczną i poczucie własnej wartości w postaci np.:

- przemocy domowej; $^{9}$

- emocjonalnego zaniedbania;

- nadużyć emocjonalnych (tj. umniejszania, dokuczania, gróźb słownych);

- molestowania, nadużycia seksualnego.

Symptomy wskazujące na rozwijanie się u dziecka zespołu stresu pourazowego można przedstawić następująco:

- ponowne odtwarzanie traumy w postaci snów, wspomnień, zabaw, a przy kontakcie z czymś, co o traumie przypomina - reaktywność fizjologiczna oraz silny dystres;

- uporczywe unikanie tematów związanych z traumą - myśli, wspomnień;

- zmniejszona ogólna reaktywność - brak zainteresowań ważnym działaniem, perspektywami na przyszłość, chłód emocjonalny;

- trwałe objawy wzmożonego pobudzenia - trudności w zasypianiu, koncentracji, czujność, drażliwość, wybuchowość ${ }^{10}$.

Trzeba jednak zaznaczyć, iż trauma relacyjna doświadczona w dzieciństwie zazwyczaj ma swe konsekwencje w dorosłym życiu danej osoby, a objawia się w jej zdrowiu fizycznym i psychicznym. Osoby takie często cierpią m.in. na:

- choroby przewlekłe (np. choroby układu oddechowego, cukrzycę);

8 S. Steuden, K. Janowski, Trauma - kontrowersje wokół pojęcia, diagnoza, następstwa, implikacje praktyczne, dz. cyt., s. 551.

9 I. Sikora, Dziecięca trauma - psychologiczne konsekwencje dla dalszego rozwoju, „Sztuka Leczenia” (2014) nr 3-4, s. 55.

10 I. Sikora, Dziecięca trauma - psychologiczne konsekwencje dla dalszego rozwoju, dz. cyt., s. 56. 
- mają trudności z odczytywaniem swoich emocji i ich regulacją;

- są mniej odporne na stres, rzadko znajdują w sobie poczucie wewnętrznego spokoju i szczęścia;

- często cierpią z powodu głębokiego poczucia osamotnienia i wewnętrznej pustki;

- mają duże problemy z nawiązywaniem i utrzymywaniem bliskich relacji ${ }^{11}$.

Wczesne doświadczenie traumy relacyjnej wpływa na powtarzanie w innych relacjach, przykładowo w dorosłym życiu, podobnego sposobu emocjonalnego przeżywania relacji. Tworzenie przywiązania zależne jest od psychobiologicznych uwarunkowań dziecka, doświadczeń opiekuna oraz mechanizmów przywiązania. Jakość wytworzonego przywiązania, a szczególnie pojawienie się traumy w obszarze relacji, odzwierciedla się w bezpośrednich, jak i oddalonych w czasie skutkach, którymi mogą być zaburzenia psychopatologiczne $e^{12}$.

Należy w tym miejscu dodać, że wiele osób, które cierpią z powodu skutków traumy relacyjnej, nie ma świadomości, że to właśnie bardzo trudne (najczęściej wczesne) doświadczenia dysfunkcji bliskiej relacji mają tak duży wpływ na ich życie. Osoby takie często obwiniają się za to, że nie radzą sobie w życiu, i wstydzą się swojego cierpienia. W takich przypadkach następstwa traumy relacyjnej zamieniają się w lęk, depresję czy żałobę, która nigdy się nie kończy ${ }^{13}$. Najdotkliwsze traumy mają swoje źródło w relacjach interpersonalnych z bliskimi osobami. Skutki ich są najbardziej bolesne i znaczące dla rozwoju osobowości, zdolności nawiązywania bliskich i zdrowych relacji ${ }^{14}$.

Z powyższego powodu możemy uznać, że istnieje istotne zagrożenie dla jakości tworzenia relacji par, które może się przekładać na traumę relacyjną par. Osoby tworzące parę wnoszą do swojej relacji nabyte doświadczenia z wcześniejszych etapów swego życia. Jeśli jakiś typ traumy stał się ich udziałem, a nie został przepracowany, to istnieje wysokie ryzyko, że będzie

\footnotetext{
11 M. Kaczmarczyk, Trauma relacyjna, https://psychoterapiacotam.pl/trauma-relacyj$\mathrm{na} /(01.12 .2018)$.

12 M. M. Migda, Trauma więzi a psychoterapia pacjentów z diagnozą PTSD w oparciu o mentalizacje, „Psychoterapia” (2013) nr 3, s. 101.

13 M. Kaczmarczyk, Trauma relacyjna, dz. cyt.

14 K. Litwińska-Rączka, Interpersonalna trauma jako „morderstwo duszy”, „Kwartalnik Naukowy Fides et Ratio" (2017) nr 4, s. 426.
} 
on oddziaływać jako czynnik negatywny, powodując traumatyzację ich więzi, ich relacji. Możemy mówić tu o swego rodzaju zjawisku przeniesienia, które powoduje przymus odgrywania w aktualnej relacji tego, czego doświadczyli we wcześniejszych, pierwotnych relacjach z osobami znaczącymi w ich życiu. Niesie to ze sobą konsekwencje w postaci wtórnej traumatyzacji doświadczanej w życiu pary. Z biegiem przeżytych wspólnie lat z powodu cykliczności swoich zachowań para dokonuje wobec siebie wielu zachowań, które odtwarzają doświadczoną wcześniej traumę. Po pewnym czasie trudno im jest rozróżnić, czy przeżywana trauma jest ich aktualnym problemem, czy pochodzi z przeszłości. W ich percepcji wszystko zaczyna się zlewać. Całe ich życie naznaczone trudem i bólem informuje, że nawet miłość do wybranej osoby nie jest wstanie uleczyć ich zranień. Dynamika tego procesu jest bardzo duża. Po pewnym czasie trudno odróżnić, kto jest ofiarą, a kto agresorem. Obie strony czują się rozczarowane sobą nawzajem, a wzajemna miłość zamienia się w silną, obopólną nienawiść, potwierdzaną różnymi aktami agresji. Trauma relacyjna pary zaczyna „wypracowywać” konkretne objawy ich zranień w postaci zaniedbywania się, narastających konfliktów, pojawiających się zdrad, uciekania się do różnego typu uzależnień (psychoaktywnych i behawioralnych), dokonanych aborcji i tym podobnych zachowań.

Po pewnym czasie relacja pary staje się wysycona problemami indywidualnymi, które zazwyczaj każde z małżonków wnosi ze swych doświadczeń rodzinnych i osobistych, oraz problemami wytworzonymi podczas trwania ich związku. Fuzja tego typu problemów mocno zaciemnia obraz ich wzajemnych relacji i przynosi bezmiar cierpienia, a także ogrom emocjonalnych zranień wewnętrznych. Dochodzi wówczas do kryzysu małżenskiego, podczas którego para zadaje sobie pytania o sens trwania ich relacji oraz powodu swoistego rodzaju fatum wiszącego na nimi od początku ich świadomości. Zazwyczaj dopiero wówczas pojawia się u nich pomysłu na odbycie wspólnej terapii małżeńskiej. Można by rzec, że ich traumy wczesnodziecięce i aktualnie doświadczane doprowadzają ich na terapię pary. Zatem wnoszone na terapię pary zagadnienia powinny mieć możliwość oddziaływać z perspektywy problemów osobistych i ich wzajemnych. 


\section{Terapia pary wobec ich traumy relacyjnej}

Terapia małżeńska jest jednym ze sposobów pomocy parze małżeńskiej w uporaniu się z kryzysem, niezależnie od tego, czy jest to kryzys „fizjologiczny", związany z przejściem z jednej fazy rozwojowej do drugiej, czy kryzys związany z przeciążeniem jednego lub obojga małżonków sytuacjami stresowymi, czy wreszcie kryzys związku związany ściśle z indywidualnymi, emocjonalnymi i osobowościowymi problemami męża lub żony ${ }^{15}$.

Podejmując się terapii pary, każdy terapeuta powinien zdawać sobie sprawę, że wnoszone przez daną parę skargi na początkowym etapie spotkań będą formułowane z perspektywy indywidualnej małżonków i z perspektywy ich relacji. Można zatem postawić zasadniczą hipotezę, że w trakcie trwania procesu terapeutycznego, na różnych jego etapach, terapeuta powinien mieć wiedzę i umiejętności związane z prowadzeniem terapii indywidualnej i małżeńskiej. Jeden lub drugi typ wyszkolenia staje się wówczas bardzo przydatny. Zwykle, choć nie z reguły, na początku bardziej przydatna jest wiedza systemowa, a w miarę trwania terapii, rozwoju przeniesienia - znajomość mechanizmów intrapsychicznych ${ }^{16}$, którymi zajmuje się np. terapia psychodynamiczna lub psychoanalityczna. $Z$ tego powodu na początku zostaną przedstawione wybrane założenia terapii pary w ujęciu systemowym, a następnie w ujęciu teorii relacji z obiektem.

W klasycznym podejściu systemowym małżeństwo/rodzina rozumiane są jako system o określonej strukturze, wzorach funkcjonowania, wzorach relacji, który aby trwać, musi się zmieniać. Funkcjonalność rodziny ocenia się poprzez to, jak członkowie rodziny radzą sobie ze zmianami wynikającymi zarówno z cyklu życia rodzinnego, czyli jej naturalnych procesów rozwojowych, jak i z nieprzewidywalnych wydarzeń losowych. Rodzina zatem w tym ujęciu jest systemem psychospołecznym, składającym się z jednostek o uwarunkowaniach biologicznych, co sprawia, że opisując ją, należy uwzględniać wszystkie trzy poziomy: biologiczny, indywidualny i społeczny. Dla jej poznania istotne jest zrozumienie zarówno tego, jaka jest struktura i relacje wewnątrzrodzinne, jak i szeroki kontekst, w jakim rodzina

15 M. Wolska, Terapia małżeńska jako jeden ze sposobów radzenia sobie w sytuacji kryzysu małżeńskiego, w: Resocjalizacja, diagnoza, wychowanie, red. B. Kosek-Nita, D. Raś, Katowice 1999, s. 77.

16 I. Namysłowska, A. Siewierska, Terapia rodziny a terapia par, „Psychoterapia” (2007) nr 3, s. 41. 
funkcjonuje. Małżeństwo i rodzina traktowane są jako system otwarty, pozostający w relacjach $\mathrm{z}$ innymi systemami ${ }^{17}$.

Psychologiczne ujęcie terminu „system” odnośnie do małżeństwa i rodziny jest identyczne jak w cybernetyce. Zasadniczym elementem cybernetycznego systemu są tzw. pętle sprzężenia zwrotnego, które stanowią elementarny model cyrkularności zwanej przyczynowością kolistą. W podejściu systemowym do rodziny przyczynowość kolista zastępuje dotychczas stosowane myślenie przyczynowo-skutkowe. Dlatego wszystkie zachowania, jakie dzieją się między ludźmi, mogą być traktowane jako pętle sprzężenia zwrotnego. Zachowanie każdej z osób wchodzących w interakcje oddziałuje na zachowania partnera interakcji, a równocześnie jest modyfikowane przez reakcję tegoż partnera. Bezużyteczny wówczas staje się model linearny, w którym zachowanie traktowane jest jako skutek czegoś ${ }^{18}$.

Z powyższego założenia wynika jedna z podstawowych właściwości w myśleniu systemowym, którą jest zasada równowagi sił. Równowaga ta nigdy nie ma charakteru biernego i statycznego. Dwie siły w kierunku odrębności, a także w kierunku bycia razem pozostają wobec siebie w ciągłym ruchu i wzajemnym oddziaływaniu. Małżeństwo/rodzina zatem jako system rozwija się, a więc zmienia się przy równoczesnej tendencji do zachowania równowagi. To dążenie do homeostazy służy do utrzymania jej własnej tożsamości ${ }^{19}$. Małżeńską/rodzinną homeostazę można opisać jako zamknięty system informacji, w którym różnice w zachowaniu służą jako informacja zwrotna, za pomocą której dokonuje się korekcja odpowiedzi systemu. Małżeństwo/rodzina zachowuje się zgodnie ze strategią jej homeostazy. Zachowania te można opisać w sposób następujący:

1) członkowie systemu starają się zachować równowagę i stałość we wzajemnych relacjach;

2) biorą oni udział w zachowaniu równowagi zarówno wprost, jak i nie wprost;

3) homeostazę można obserwować poprzez powtarzające się, dające się przewidzieć wzorce zachowań wszystkich członków rodziny;

17 B. Józefik, Rozwój myślenia systemowego a terapia rodzin, w: Ewolucja myślenia systemowego $w$ terapii rodzin. Od metafory cybernetycznej do dialogu i narracji, red. L. Górniak, B. Józefik, Kraków 2003, s. 25.

18 L. Drożdżowicz, Ogólna teoria systemów, w: Wprowadzenie do systemowego rozumienia rodziny, red. B. de Barbaro, Kraków 1999, s. 14.

19 Por. K. Ostoja-Zawadzka, Cykl życia rodzinnego, w: Wprowadzenie do systemowego rozumienia rodziny, dz. cyt. Kraków 1999, s. 18-30. 
4) kiedy równowadze małżeńskiej/rodzinnej zagraża destabilizacja, wszyscy członkowie zgodnie podejmują działania, aby ją utrzymać;

5) kiedy jeden $\mathrm{z}$ członków sygnalizuje chęć zmiany w relacji $\mathrm{z}$ innym, ten będzie zachowywał się tak, aby zmniejszyć lub zmodyfikować tę tendencję ${ }^{20}$.

Ujęcie terapii systemowej zakłada, że zdiagnozowany problem u klienta może być objawem tego, jak funkcjonuje system, a nie jest to tylko symptom złego dostosowania się danego człowieka, wynikający z historii jego życia i rozwoju psychospołecznego. Taka perspektywa teoretyczna jest oparta na założeniu, że zachowanie klienta, które stwarza problemy, może:

1) służyć jakiemuś celowi w małżeństwie/rodzinie;

2) być funkcją niezdolności małżeństwa/rodziny do produktywnego działania, zwłaszcza podczas przejścia z jednego na drugi etap rozwoju;

3) być symptomem wzorców dysfunkcjonalnych, które są przekazywane z pokolenia na pokolenie. Wszystkie wymienione założenia kwestionują bardziej tradycyjne, intrapsychiczne ramy, których używano do konceptualizacji problemów ludzkich i wyjaśniania ich genezy ${ }^{21}$.

W ujęciu systemowym podstawowe cechy małżeństwa/rodziny dysfunkcjonalnej ujmuje się w kilku sferach działania:

1) małżeństwo/rodzina dysfunkcyjna są zamknięte, ich członkowie żyją w izolacji od świata zewnętrznego, bliskich kontaktów towarzyskich, przyjaźni bądź też kontakty te są powierzchowne, konwencjonalne, dominują w nich pozory, brak prawdziwych uczuć; ma miejsce nieszczerość oraz niezdolność do zwracania się o pomoc;

2) małżeństwo/rodzina takie żyją w zakłamaniu, braku szczerości i mówienia prawdy o problemach nękających członków rodziny, fałszując i zniekształcając rzeczywistość;

3) w małżeństwie/rodzinie takich brakuje wzajemności, czyli albo nikt nikomu nie pomaga, każdy jest skoncentrowany na sobie, a problemy innych członków są ignorowane, albo też oparte są na nadopiekuńczości jednych wobec drugich;

\footnotetext{
20 I. Namysłowska, Terapia rodzin, Warszawa 1997, s. 33-34.

21 G. Corey, Teoria i praktyka poradnictwa i psychoterapii, przeł. K. Mazurek, Poznań
} 2005, s. 508. 
4) małżeństwo/rodzinę dysfunkcyjne cechuje sztywny podział ról, nieadekwatne widzenie świata i danych zachowań, które obowiązują nawet wtedy, gdy nie ma już potrzeby kierowania się wyuczonymi, obronnymi reakcjami ${ }^{22}$.

Ogólnie można skonstatować, że wynikiem braku równowagi pomiędzy dystansem i bliskością, byciem razem i osobno, zależnością i niezależnością w relacjach małżeńsko-rodzinnych jest lęk, który leży u podstaw procesów emocjonalnych w jednostce i małżeństwie/rodzinie. Według Murraya Bowena mechanizmami pozwalającymi utrzymać stabilność emocjonalną są:

- konflikt małżeński;

- dystans emocjonalny;

- dysfunkcja jednego z małżonków;

przeniesienie problemów na jedno lub więcej dzieci ${ }^{23}$.

Cele terapii pary/małżeńskiej w kontekście powyższych procesów emocjonalnych są następujące:

- zwiększenie stopnia zróżnicowania poszczególnych małżonków i systemu małżeńskiego (intelektualno-emocjonalnego);

- proces różnicowania polega na inicjowaniu i wspieraniu powolnego procesu eksternalizacji i oddzielaniu fantazji, uczuć i myśli współmałżonków od siebie - niezależność;

- zwiększenie zdolności do mentalizacji;

- pomieszczanie uczuć w sobie oraz ich werbalizacja;

- detriangulacja - wstępna i zstępna oraz pozarodzinna;

- zainteresowanie rodzinami pochodzenia w terapii par - geneogram.

Terapia systemowa ze swej istoty ma charakter procesu, który rozkłada się w czasie w zależności od sygnalizowanego problemu małżeńsko-rodzinnego i wielu innych zmiennych. Zwykle wyróżnia się 3 stadia: początkowe, środkowe i końcowe ${ }^{24}$. Możliwy jest także inny podział, który wyróżnia następujące etapy:

1) Faza nawiązania kontaktu - celem tego etapu spotkań jest wytworzenie właściwej, czyli wewnętrznej i możliwie głębokiej motywacji do terapii

22 M. Ryś, Znaczenie relacji $w$ rodzinie. Wpływ oddziaływania prawidłowych i nieprawidłowych systemów rodzinnych, w: Małżeństwo i rodzina w panoramie współczesnych systemów, red. A. Offmański, Szczecin 2006, s. 79.

23 I. Namysłowska, Terapia rodzin, dz. cyt., s. 86.

24 Zob. S. Kratochvil, Terapia małżeńska, tłum. Biuro tłumaczeń ITAMAR, Gdańsk 2006, s. 187-191. 
członków systemu. Miarą tego jest stopniowe nabywanie przekonania u każdej osoby, że praca ta będzie się odbywała w jego interesie, a równocześnie korzyści z tego procesu będzie miała cała wspólnota. Jest to możliwe, gdy kontakt zostanie nawiązany w taki sposób, że poczuje się ona bezpiecznie. Wzajemne poznawanie się systemu i doradcy (doradców) warto przedłużyć, tak aby wszyscy odczuli, że mają wpływ na to, co się będzie działo.

2) Faza opisu problemu - celem rozmów na tym etapie jest prawdziwy i szczegółowy opis problemów, z jakim spotyka się dany system w swoim funkcjonowaniu. Zwykle budzi to duży opór wszystkich jej członków. Ważne jest, by wszyscy wyrazili swoje zdanie i pogląd na temat zachodzących zjawisk, tak by nie podtrzymywać tajemnic rodzinnych, gdyż aby coś się mogło skończyć, trzeba do tego wrócić, omówić to, przeżyć i zrozumieć w inny niż dotychczas sposób; i dopiero wówczas zamknąć. To, co istotne na tym etapie, to prowadzenie rozmów w taki sposób, aby można było podczas nich poruszać najważniejsze, a równocześnie najtrudniejsze dla systemu sprawy.

3) Faza uzgodnienia warunków procesu doradzania - najważniejszym i być może najtrudniejszym do spełnienia warunkiem uczestnictwa w procesie jest ustanie w systemie danego negatywnego symptomu lub zachowania. Aby to ułatwić, dokonuje się wspólnie swoistego bilansu zysków i strat, do których dane zachowanie doprowadza. Nie potępia się tutaj człowieka, lecz jego zachowanie, które uznaje się za niedopuszczalne i szkodliwe.

4) Faza pracy terapeutycznej nad problemami - celem tej fazy jest stworzenie emocjonalnych warunków do zmiany w zachowaniu całego sytemu. Aby to wszystko mogło zaistnieć, trzeba prowadzić rozmowy w taki sposób, by szanowano opinie wszystkich członków, by osoba, która mówi, była nie tylko słuchana, ale i zrozumiana.

5) Faza towarzyszenia systemowi w dalszych zmianach - celem tego etapu jest praca nad znalezieniem i utrwaleniem nowych wzorców funkcjonowania i relacji. Doradcy czuwają nad bezpieczeństwem każdego podsystemu i stwarzają im możliwości rozwoju i zmian ${ }^{25}$.

Diagnozę systemową stawiamy zwykle w obrębie interakcji i transakcji, relacji i zachowań partnerów wobec siebie. Później pogłębiamy ją o aspekty historyczne, w tym międzypokoleniowe. Punktem wyjścia dla terapeuty

25 W. Szaszkiewicz, Systemowa terapia rodziny z problemem przemocy $i$ uzależnienia, „Terapia Uzależnienia i Współuzależnienia” (2008) nr 4, s. 9-11. 
rodzin czy par jest więc problem określony z perspektywy behawioralnej i interakcyjnej, a nie wynikający bezpośrednio z określenia struktury osobowości ${ }^{26}$. Dlatego niezwykle pomocną staje się terapia psychoanalityczna lub psychodynamiczna.

Podejście psychoanalityczne zawiera w sobie m.in. teorię relacji z obiektem, która z założenia skupia swoją uważność na indywidualnym kliencie i jego relacji z istotny obiektem. Melanie Klein wskazała, że ludzie wchodzą w relacje nieświadomie, w drodze projekcji umieszczając części siebie, które odczuwają jako zagrażające, w innych osobach. Ten nieświadomy mechanizm występuje we wszystkich bliskich związkach. Zaczyna się w relacji $\mathrm{z}$ rodzicem, a później trwa w innych relacjach w ciągu całego życia. Części te wchodzą w interakcje z organizacją psychiczną drugiej osoby i mogą powodować identyfikowanie się ze stanami osoby oddziałującej projekcyjnie identyfikacja projekcyjna. Jej odbiorca przyjmuje te aspekty drugiej osoby $\mathrm{w}$ drodze introjekcyjnej identyfikacji ${ }^{27}$.

Henry Dicks zauważył, że w stosunkowo zdrowych parach często ujawniają się prymitywne relacje z obiektem. Doszedł wówczas do wniosku, że jednym z podstawowych źródeł małżeńskiej niezgody jest przeniesieniowe postrzeganie partnera i niezdolność uznania jego odrębnej tożsamości czy natury. Pary z czasem zaczynają tworzyć spolaryzowane układy: sadystyczno-masochistyczny, dominująco-uległy, zdrowy-chory, niezależny-zależny. Spolaryzowane połówki tworzą pełną osobowość w małżeńskiej diadzie, natomiast każde $\mathrm{z}$ małżonków $\mathrm{z}$ osobna jest niekompletne. W małżeństwie przeżywającym trudności każde z partnerów odnosi się do drugiego w kategoriach nieświadomych potrzeb i spostrzega go w pewnym stopniu jako zinternalizowany obiekt; oboje funkcjonują razem jako połączona osobowośćc ${ }^{28}$.

Podczas terapii par bardzo często nawraca rozgrywanie podstawowych konfliktów wewnętrznych partnerów. W terapii par odwołującej się do teorii relacji z obiektem rozegrania można rozumieć jako manifestację projektowania w partnera swoich wewnętrznych obiektów. Oznacza to, że np. uwewnętrznione na wczesnych etapach rozwoju doświadczenie odrzucającego obiektu jest umieszczane w partnerze, który jest przeżywany

\footnotetext{
26 M. Furgał, B. Janusz, Doświadczenie impasu w terapii par osób z przewaga pierwotnych mechanizmów obronnych. Między bezradnościa a szansą na rozwój i zmianę, „Psychoterapia" (2016) nr 2, s. 58.

27 M. Furgał, B. Janusz, Doświadczenie impasu w terapii par osób..., dz. cyt., s. 59.

28 M. Furgał, B. Janusz, Doświadczenie impasu w terapii par osób..., dz. cyt., s. 60.
} 
jako odrzucający. Tego rodzaju projekcja pozwala na pozbycie się chwilowo tego przykrego doświadczenia i przeżywanie przykrości jako płynącej z zewnątrz. Drugi partner, identyfikując się z projekcją pierwszego, zaczyna wycofywać się z relacji. To rozegranie powoduje, że odrzucenie się urzeczywistnia. To rozumienie pozwala sformułować ważne pytania, na ile w terapii par może dojść do przestrukturowania obiektów wewnętrznych, na ile partnerzy mogą stać się obiektami rzeczywistymi, a nie obiektami projekcji, i na ile wreszcie relacja $\mathrm{z}$ partnerem może zostać uwewnętrzniona jako relacja $\mathrm{z}$ obiektem zaspokajającym potrzeby. Tego rodzaju interakcja wraca wielokrotnie $\mathrm{w}$ toku pracy terapeutycznej i nie zawsze może zostać przerwana przez terapeutę. Spełnia ona bowiem ważne funkcje dla pierwszego partnera, który przez projekcję przez chwilę nie czuje w sobie samym odrzucenia ${ }^{29}$.

Powyższe spostrzeżenia odnośnie do poszczególnych kierunków pracy terapeutycznej z potrzebującą pomocy parą pozwalają postawić taki wniosek, że by ich proces terapeutyczny mógł przebiegać konstruktywnie i owocnie, terapeuta powinien mieć umiejętności łączenia diagnozy, pracy terapeutycznej z perspektywy całego systemu oraz ich osobistych konfliktów wewnętrznych. Trauma relacyjna jest szczególnym wyzwaniem dla procesu terapeutycznego. Jej etiologia oraz aktualne rozgrywania w parach potrzebujących wsparcia bardzo mocno utrudniają wcielenie w proces terapeutyczny strategii wywodzącej się z jednej koncepcji psychologicznej. Wartością dodaną terapii pary doświadczającej następstw traumy relacyjnej jest potencjalna możliwość wprowadzenia zmiany w sposobie funkcjonowania jednostki i budowania relacji w parze.

Praca terapeutyczna z osobami doświadczającymi traumy relacyjnej jest długotrwałym i skomplikowanym procesem. Jednym z ważniejszych momentów, jaki dana para może doznać w trakcie terapii, jest uświadomienie sobie znaczenia traum, jakich doświadczyło się w relacjach z osobami znaczącymi na wczesnych etapach indywidualnego rozwoju. Nazwanie tych osobistych traum wobec partnera, z którym jest się w bliskiej relacji, pozwala zrozumieć mechanizm rozgrywający się między nimi w ich aktualnej sytuacji życiowej. Choć to trudny i bolesny aspekt terapii pary, to jest on punktem zwrotnym w dalszym ich poszukiwaniu harmonijnego funkcjonowania. Trauma relacyjna wydaje się dość powszechnym elementem

29 M. Furgał, B. Janusz, Doświadczenie impasu w terapii par osób..., dz. cyt., s. 62. 
funkcjonowania wielu par. Nie wszystkie jednak pary są wstanie rozpoznać jej znaczenie i następnie je przepracować. Bardzo często dochodzi wówczas do rozpadu związku lub wikłania kolejnego pokolenia poprzez odtworzenie traumy wobec nich. Dokonuje się to bezwiednie i jest następstwem swoistego rodzaju bezradności osób, którzy naznaczeni zostali traumatycznym doświadczeniem. Terapia takich par jest długotrwałym procesem, daje jednak pewną szansę na wprowadzenie pozytywnych zmian.

\section{Bibliografia}

Corey G., Teoria i praktyka poradnictwa i psychoterapii, przeł. K. Mazurek, Poznań 2005.

Drożdżowicz L., Ogólna teoria systemów, w: Wprowadzenie do systemowego rozumienia rodziny, red. B. de Barbaro, Kraków 1999, s. 9-17.

Furgał M., Janusz B., Doświadczenie impasu w terapii par osób z przewaga pierwotnych mechanizmów obronnych. Między bezradnością a szansą na rozwój i zmianę, „Psychoterapia” (2016) nr 2, s. 57-67.

Herbert C., Zrozumieć traumę - poradnik dla osób, które doznały urazu i dla ich rodzin, Gdańsk 2004.

Jankowska A., Lotkowski M., Przeżywanie stresu traumatycznego w rodzinie - przyczyny, przebieg, następstwa oraz proces zdrowienia, „Kwartalnik Naukowy - Fides et Ratio" (2012) nr 1, s. 69-89.

Józefik B., Rozwój myślenia systemowego a terapia rodzin, w: Ewolucja myślenia systemowego $w$ terapii rodzin. Od metafory cybernetycznej do dialogu i narracji, red. L. Górniak, B. Józefik, Kraków 2003, s. 19-31.

Kaczmarczyk M., Trauma relacyjna, https://psychoterapiacotam.pl/trauma-relacyjna/ (01.12.2018).

Kratochvil S., Terapia małżeńska, tłum. Biuro tłumaczeń ITAMAR, Gdańsk 2006.

Litwińska-Rączka K., Interpersonalna trauma jako "morderstwo duszy”, „Kwartalnik Naukowy Fides et Ratio” (2017), nr 4, s. 420-427.

Migda M.M., Trauma więzi a psychoterapia pacjentów zdiagnoza PTSD w oparciu o mentalizacje, „Psychoterapia” (2013) nr 3, s. 99-105.

Namysłowska I., Siewierska A., Terapia rodziny a terapia par, „Psychoterapia” (2007) nr 3, s. 37-42. 
Namysłowska I., Terapia rodzin, Warszawa 1997.

Ogińska-Bulik N., Negatywne i pozytywne następstwa doświadczonej traumy - rola ruminacji, „Psychiatria, Psychologia Kliniczna” (2016) nr 3, s. $182-187$.

Ostoja-Zawadzka K., Cykl życia rodzinnego, w: Wprowadzenie do systemowego rozumienia rodziny, red. B. de Barbaro, Kraków 1999, s. 18-30.

Popiel A., Pragłowska E., Psychopatologia reakcji na traumatyczne wydarzenia, w: Konsekwencje psychiczne traumy - uwarunkowania i terapia, red. J. Strelau, B. Zawadzki, M. Kaczmarek, Warszawa 2009, s. 34-63.

Ryś M., Znaczenie relacji w rodzinie. Wpływ oddzialywania prawidłowych i nieprawidłowych systemów rodzinnych, w: Małżeństwo i rodzina w panoramie współczesnych systemów, red. A. Offmański, Szczecin 2006, s. 71-93.

Sikora I., Dziecięca trauma - psychologiczne konsekwencje dla dalszego rozwoju, „Sztuka Leczenia” (2014) nr 3-4, s. 55-70.

Steuden S., Janowski K., Trauma - kontrowersje wokół pojęcia, diagnoza, następstwa, implikacje praktyczne, „Roczniki Psychologiczne” (2016) nr 3, s. 549-565.

Szaszkiewicz W., Systemowa terapia rodziny z problemem przemocy i uzależnienia, „Terapia Uzależnienia i Współuzależnienia” (2008) nr 4, s. 9-11.

Wolska M., Terapia małżeńska jako jeden ze sposobów radzenia sobie w sytuacji kryzysu małżeńskiego, w: Resocjalizacja, diagnoza, wychowanie, red. B. Kosek-Nita, D. Raś, Katowice 1999, s. 76-96. 
